\title{
Development of intestinal microflora and occurrence of diarrhoea in sucking foals: effects of Bacillus cereus var. toyoi supplementation
}

\author{
Jenny John ${ }^{1,4}$, Kathrin Roediger ${ }^{2}$, Wieland Schroedl ${ }^{3}$, Nada Aldaher ${ }^{3}$ and Ingrid Vervuert ${ }^{{ }^{*}}$
}

\begin{abstract}
Background: Almost all foals develop transient diarrhoea within the first weeks of life. Studies indicated different viral, bacterial, and parasitic causes, such as rotavirus, Clostridium perfringens, Escherichia coli, and Cryptosporidium are discussed. But little is known about the development of intestinal microflora in foals. The present study investigated whether the supplementation with Bacillus cereus var. toyoi would modify the developing intestinal microflora and consequently reduce diarrhoea in foals. From birth, the foals were randomly assigned to three treatment groups: placebo (10 mL isotonic $\mathrm{NaCl}, n=8)$, low dosage ( $\mathrm{LD} ; 5 \times 10^{8} \mathrm{cfu}$ B. cereus var. toyoi, $\left.n=7\right)$ and high dosage (HD; $2 \times 10^{9}$ cfu B. cereus var. toyoi, $n=10$ ). Treatment groups were supplemented orally once a day for 58 days. Faeces scoring and sampling were performed within the first $24 \mathrm{~h}$ after birth and on day 9, 16, 23, 30, 44, 58 of the foal's life and also on the first day of diarrhoea. Culture-plate methods were used to analyse the bacterial microflora.
\end{abstract}

Results: Eighty-eight per cent of the foals developed diarrhoea (placebo 7/8, LD 5/7, HD 10/10) during the first 58 days of life. Bacillus cereus var. toyoi supplementation had no effect on bacterial microflora. Clostridium perfringens and enterobacteria were equally prevalent in foals with diarrhoea and those who were not afflicted.

Conclusions: We conclude that the supplementation of B. cereus var. toyoi had no effect on the occurrence of diarrhoea and health status in the foals.

Keywords: Microflora, Foal, Diarrhoea, Probiotic, Bacillus cereus var. toyoi

\section{Background}

Diarrhoea is a common problem in neonatal foals. Almost all foals develop transient diarrhoea within the first weeks of life $[1,2]$. Studies have reported different viral, bacterial, and parasitic causes [3-6]. Between the days 5 and 15 of a foal's life, when the dam's first post partum oestrus is expected, diarrhoea in foals is observed frequently [3]. The diarrhoea is termed 'foal heat diarrhoea'. Although commonly there is no reduction in behaviour of the foals, some of them suffer from diarrhoea more than 20 days within the first 2 months of life and develop not as good as foals with shorter diarrhoea periods. The establishment of intestinal microflora and maturation of the gastrointestinal mucosa are some reasons proposed for diarrhoea in this period of life [2].

\footnotetext{
* Correspondence: ingrid.vervuert@vetmed.uni-leipzig.de

'Institute of Animal Nutrition, Nutrition Diseases and Dietetics, Faculty of

Veterinary Medicine, University of Leipzig, Leipzig, Germany

Full list of author information is available at the end of the article
}

However, little is known about the development of the intestinal microflora during this period. During and following birth, neonates are exposed to a variety of microorganisms originally from the dam or environment. On the day of birth, aerobes, facultative anaerobes, and strict anaerobes were already detected in the faeces of the foals [7]. Before foals are fed solid food, cellulolytic bacteria have already colonized the digestive tract [7]. Because the intestinal microflora is a crucial line of resistance against colonization by exogenous microbes, it is highly relevant in the prevention of tissue invasion by pathogens [8].

Probiotic bacteria were defined by a joint FAO, WHO [9] as 'live microorganism which when administered in adequate amounts confer a health benefit on the host'. Some probiotics are known to have a positive effect on the intestinal microflora. For example, Yuyama et al. [10] reported that supplementation with probiotics led to an earlier recovery from foal heat diarrhoea, probably by enhancing establishment of the normal intestinal 
microflora. However, other studies that showed that supplementation with probiotics in foals increased the occurrence and duration of diarrhoea compared to placebo-treated foals [11], and Weese and Rousseau [12] reported that probiotic administration was significantly associated with development of signs of depression, anorexia, and colic in foals.

The aim of the study was to investigate the effects of oral probiotic supplementation on the growing intestinal microflora in equine neonates. Previous studies have shown positive effects of Bacillus cereus var. toyoi on intestinal health in calves, piglets, poultry, broiler chickens, and growing rabbits [13-16]. Baum et al. [17] observed trophic effects of Bacillus cereus var. toyoi on the small intestinal mucosa of pigs as demonstrated by longer villi, thicker mucosa and more mature, i.e. acidic mucins. Vilà et al. [15] showed that feeding of Bacillus cereus var. toyoi reduced the prevalence of pathogens such as Salmonella in poultry and improved the performance variables of broiler chickens. We hypothesized that oral supplementation with B. cereus var. toyoi from birth until 2 months of the foal's life would modify the intestinal microflora and mucosa, and therefore lead to a reduction of diarrhoea in foals.

\section{Results}

During the observation period, haematolgy parameters like erythrocytes, haematocrit or leukocytes were in the reference range obtained for foals (data not shown, treatment $\mathrm{p}>0.05)$. $24 \mathrm{~h}$ after birth serum IgG levels were always higher than the lowest critical threshold of $8 \mathrm{~g} / \mathrm{L}$. Serum IgG levels of the foals were in median between $17.1 \mathrm{~g} / \mathrm{l}$ and $25.6 \mathrm{~g} / \mathrm{l}$ (treatment $\mathrm{p}>0.05$ ). During the observation period, serum IgG levels decreased down to $60-70 \%$ of initial value at day 58 (time $\mathrm{p}<0.05$, treatment $\mathrm{p}>0.05$ ). Diarrhoea occurred in up to $90 \%$ of the foals for at least one 1 day between days 8 and 16 of life. In particular, during transition period between orange-brown milk faeces and more adult-like greenish faeces a loose consistency (faeces score: 6-9) was observed in $92 \%$ of the foals. Despite this, foals remained bright and alert and continued to nurse.

Supplementation with B. cereus var. toyoi had no significant effect on dry matter content of the faeces of the foals. Furthermore, supplementation with $B$. cereus var. toyoi had no significant effect on blood parameters and there was no change in the incidence of diarrhoea in foals in the first 58 days of life (Table 1).

Lactobacilli in the foals faeces increased on days 1 to 9 of foals life. Maximum level was $4.50 \times 10^{7} \mathrm{cfu} / \mathrm{g}$ (LD, Table 2). Declining counts of Lactobacilli were noticed until day 58 where Lactobacilli counts almost reached the levels of the mares (measured at the time of birth).
Table 1 Number of foals with diarrhoea, duration of diarrhoea (days) and faecal score in placebo $(n=8)$, low dosage $(n=7)$, and high dosage $(n=10)$ during period of oral supplementation with Bacillus cereus var. toyoi (days 1 to 58 of life), data expressed as numbers, median, 25 and $75 \%$ quartile

\begin{tabular}{|c|c|c|c|c|}
\hline Item & Placebo & Low dosage & High dosage & P-value \\
\hline \multicolumn{5}{|c|}{ Number of foals with diarrhoea (n) } \\
\hline & $7 / 8$ & $5 / 7$ & $10 / 10$ & $>0.05$ \\
\hline \multicolumn{5}{|c|}{ Duration of diarrhoea (days) } \\
\hline $25 \%$ quartile & 2 & 2 & 2.8 & 0.7072 \\
\hline Median & 2.5 & 10 & 3.5 & \\
\hline $75 \%$ quartile & 5.3 & 11 & 4.8 & \\
\hline \multicolumn{5}{|l|}{ Faecal score } \\
\hline $25 \%$ quartile & 3 & 2 & 2 & 0.132 \\
\hline Median & 3 & 3 & 3 & \\
\hline $75 \%$ quartile & 3 & 6 & 5 & \\
\hline
\end{tabular}

Supplementation with B. cereus var. toyoi had no significant effect on lactobacilli counts in faeces of the foals.

Both frequency of detection (Table 3) and bacteria counts of enterococci (data not shown) in the faeces of the foals increased in the first 9 days of life and then declined until day 58 . Enterococci were found in $15.2 \%$ of the mares samples (measured at the time of birth). Supplementation with $B$. cereus var. toyoi had no significant effect on enterococci counts in faeces of the foals.

Bacteroides spp. were detected in the faeces of three foals respectively in one to three samples between days 9 and 30 of life. Two out of three foals had days of diarrhoea above-the average. Four out of six samples with Bacteroides spp. were samples from diarrhoea. No Bacteroides spp. were found in the mares samples (data not shown).

Enterobacteria were not detected in faeces of the foals at every time point during the treatment period (days 1 to 58 of life, Table 4). Enterobacteria were found in 30\% (10 of 33) of the mare samples (measured at the time of birth), at a maximum of $6.00 \times 10^{5} \mathrm{cfu} / \mathrm{g}$ (data not shown). Enterobacteria were equally prevalent in foals with diarrhoea and in foals those not afflicted (data not shown). No significant treatment effect was observed for enterobacteria.

In the first faeces of the foals after meconium, Clostridium perfringens was detectable in $50-71 \%$ of the samples (Table 5). In the placebo group, C. perfringens was detectable in $100 \%$ of the foals on day 3 . Among all groups, the maximum count was $6.00 \times 10^{6} \mathrm{cfu} / \mathrm{g}$ on day 3. C. perfringens was found in $75 \%$ of the mare samples (measured at the time of birth) and ranged from $1.00 \times$ $10^{3}$ to $2.50 \times 10^{5} \mathrm{cfu} / \mathrm{g}$ (data not shown). Clostridium perfringens was equally prevalent in foals with or without 
Table 2 Lactobacilli in faeces (cfu/g) of the foals from days 1 to 58 of life in placebo, low dosage (LD), and high dosage (HD) groups and for all foals, data expressed as numbers, median, 25 and $75 \%$ quartile, time $p=0.002$, treatment $p=0.522$

\begin{tabular}{|c|c|c|c|c|c|c|c|c|c|}
\hline \multirow[t]{2}{*}{ Group } & \multirow[t]{2}{*}{ Measure } & \multicolumn{8}{|c|}{ Day of foal's life } \\
\hline & & 1 & 3 & 9 & 16 & 23 & 30 & 44 & 58 \\
\hline \multirow[t]{3}{*}{ Placebo } & $25 \%$ quartile & $2.8 \times 10^{4}$ & $2.7 \times 10^{6}$ & $3.2 \times 10^{6}$ & $2.1 \times 10^{6}$ & $2.9 \times 10^{5}$ & $5.0 \times 10^{5}$ & $4.3 \times 10^{5}$ & $4.1 \times 10^{4}$ \\
\hline & Median & $3.4 \times 10^{4}$ & $1.7 \times 10^{7}$ & $2.5 \times 10^{7}$ & $2.0 \times 10^{7}$ & $1.4 \times 10^{6}$ & $1.0 \times 10^{6}$ & $1.9 \times 10^{6}$ & $2.2 \times 10^{5}$ \\
\hline & 75\% quartile & $4.0 \times 10^{5}$ & $8.3 \times 10^{7}$ & $4.0 \times 10^{7}$ & $3.0 \times 10^{7}$ & $5.0 \times 10^{6}$ & $2.5 \times 10^{6}$ & $2.6 \times 10^{6}$ & $3.3 \times 10^{5}$ \\
\hline \multirow[t]{3}{*}{ LD } & $25 \%$ quartile & $1.9 \times 10^{4}$ & n.d. & $8.2 \times 10^{6}$ & $3.6 \times 10^{6}$ & $2.5 \times 10^{5}$ & $2.8 \times 10^{5}$ & $3.4 \times 10^{5}$ & $2.7 \times 10^{5}$ \\
\hline & Median & $4.0 \times 10^{5}$ & n.d. & $4.5 \times 10^{7}$ & $5.5 \times 10^{6}$ & $5.4 \times 10^{5}$ & $3.9 \times 10^{5}$ & $4.0 \times 10^{5}$ & $6.0 \times 10^{5}$ \\
\hline & $75 \%$ quartile & $2.0 \times 10^{6}$ & n.d. & $6.7 \times 10^{7}$ & $1.9 \times 10^{7}$ & $2.9 \times 10^{6}$ & $4.2 \times 10^{5}$ & $5.4 \times 10^{5}$ & $9.7 \times 10^{5}$ \\
\hline \multirow[t]{3}{*}{ HD } & $25 \%$ quartile & $7.0 \times 10^{3}$ & $2.3 \times 10^{6}$ & $4.7 \times 10^{6}$ & $4.2 \times 10^{6}$ & $2.7 \times 10^{5}$ & $3.1 \times 10^{5}$ & $1.4 \times 10^{5}$ & $1.5 \times 10^{5}$ \\
\hline & Median & $2.5 \times 10^{4}$ & $3.7 \times 10^{6}$ & $2.1 \times 10^{7}$ & $1.5 \times 10^{7}$ & $1.6 \times 10^{6}$ & $2.7 \times 10^{6}$ & $4.3 \times 10^{5}$ & $4.9 \times 10^{5}$ \\
\hline & $75 \%$ quartile & $2.3 \times 10^{6}$ & $3.8 \times 10^{7}$ & $4.6 \times 10^{7}$ & $4.6 \times 10^{7}$ & $1.3 \times 10^{7}$ & $7.1 \times 10^{6}$ & $7.3 \times 10^{5}$ & $4.4 \times 10^{6}$ \\
\hline \multirow[t]{3}{*}{ Total } & $25 \%$ quartile & $1.6 \times 10^{4}$ & $2.3 \times 10^{6}$ & $3.5 \times 10^{6}$ & $3.2 \times 10^{6}$ & $1.9 \times 10^{5}$ & $2.5 \times 10^{5}$ & $2.7 \times 10^{5}$ & $1.9 \times 10^{5}$ \\
\hline & Median & $3.4 \times 10^{4}$ & $3.7 \times 10^{6}$ & $2.3 \times 10^{7}$ & $1.7 \times 10^{6}$ & $1.3 \times 10^{6}$ & $6.0 \times 10^{5}$ & $5.0 \times 10^{5}$ & $3.2 \times 10^{5}$ \\
\hline & $75 \%$ quartile & $2.2 \times 10^{6}$ & $4.5 \times 10^{7}$ & $5.0 \times 10^{7}$ & $2.8 \times 10^{7}$ & $5.0 \times 10^{6}$ & $2.9 \times 10^{6}$ & $1.2 \times 10^{6}$ & $1.0 \times 10^{6}$ \\
\hline
\end{tabular}

n.d.: non-determinable, total: over all treatments.

diarrhoea (data not shown). Supplementation with B. cereus var. toyoi had no significant effect on $C$. perfringens.

Occasionally yeasts were found in samples of the mares ( 2 out of 24 samples) and the foals (17 out of 191 samples, data not shown).

\section{Discussion}

The present study was performed on a studfarm under typical field conditions. To minimize effects related to husbandry, feeding, and season, our study took place at one thoroughbred farm, within one foaling period from February to May. According to Lahrssen and Zentek [18] such a study design is important when working with a limited number of animals. Probiotic dosing and treatment period were in accordance with studies by Jeroch et al. [19], Jadamus et al. [20], and Vilà et al. [15].

Unfortunately some foals were treated with antibiotics during a severe period of illness which may have an impact on the subsequent microbial profile in faeces.

Bacterial microflora in faeces was used as an indication of the effects of $B$. cereus var. toyoi on the intestinal

Table 3 Detection rate ( $>10^{3} \mathrm{cfu} / \mathrm{g}, \%$ ) of enterococci in faeces of the foals from days 1 to 58 of life in placebo, low dosage (LD), and high dosage (HD) groups and for all foals, data expressed in \%, treatment $p>0.05$

\begin{tabular}{lllllllll}
\hline Group & \multicolumn{6}{l}{ Day of foal's life } \\
\cline { 2 - 8 } & $\mathbf{1}$ & $\mathbf{3}$ & $\mathbf{9}$ & $\mathbf{1 6}$ & $\mathbf{2 3}$ & $\mathbf{3 0}$ & $\mathbf{4 4}$ & $\mathbf{5 8}$ \\
\hline Placebo & $66,7 \%$ & $100.0 \%$ & $85.7 \%$ & $50.0 \%$ & $50.0 \%$ & $25.0 \%$ & $25.0 \%$ & $12.5 \%$ \\
LD & $57.1 \%$ & n.d. & $85.7 \%$ & $85.7 \%$ & $42.9 \%$ & $42.9 \%$ & $42.9 \%$ & $14.3 \%$ \\
HD & $60.0 \%$ & $83.3 \%$ & $100.0 \%$ & $60.0 \%$ & $40.0 \%$ & $40.0 \%$ & $40.0 \%$ & $30.0 \%$ \\
Total & $61.1 \%$ & $90.0 \%$ & $91.7 \%$ & $64.0 \%$ & $44.0 \%$ & $36.0 \%$ & $36.0 \%$ & $20.0 \%$
\end{tabular}

n.d.: non-determinable, total: over all treatments. health of foals. Although faeces might have some limitations for describing the gut ecosystem, by comparing microflora and the digestion process in the colon with faeces in fistulated horses Julliand and Goachet [21] showed that the faecal ecosystem is an appropriate marker of intestinal changes appearing in the colon ecosystem.

Culture-plate methods were used to access bacterial microflora in the faeces of the foals to establish basic knowledge. For following studies culture-dependent methods should be extended by PCR methods to improve knowledge about diversity of genes.

In our study, diarrhoea did not lead to changes in normal foal behaviour. Foals remained bright and alert and continued to nurse. Clinical parameters including heart and respiratory rate, body temperature, and body weight were in the proper physiological range. We conclude that diarrhoea in foals between days 6 and 16 of the foal's life is not primarily pathogen related. During this period, we observed diarrhoea when orange-brownish faeces changed to green, soft faeces. These changes in faeces colour might mark the transition from only digestion of milk to increasing digestion of solid nutrients like crude fibre. In that context, hemicellulose and cellulose could be responsible for a higher water-binding capacity and a reduction of intestinal passage. As a result, adsorptive and secretory intestinal processes are influenced and free water in the colon could simulate lower dry matter content in faeces of the foals. Another reason for the reduction of dry matter content in faeces could be osmotically-acting metabolites of bacterial digestion of crude fibre.

Meconium has been reported to be free of bacteria [22] and no bacterial PCR products were obtained from 


\begin{tabular}{|c|c|c|c|c|c|c|c|c|}
\hline \multirow[t]{2}{*}{ Group } & \multicolumn{8}{|c|}{ Day of foal's life } \\
\hline & 1 & 3 & 9 & 16 & 23 & 30 & 44 & 58 \\
\hline Placebo & $0 \%$ & $25.0 \%$ & $14.3 \%$ & $25.0 \%$ & $25.0 \%$ & $37.5 \%$ & $37.5 \%$ & $50.0 \%$ \\
\hline LD & $28.6 \%$ & n.d. & $42.9 \%$ & $42.9 \%$ & $42.9 \%$ & $57.1 \%$ & $28.6 \%$ & $57.1 \%$ \\
\hline HD & $20.0 \%$ & $16.7 \%$ & $60.0 \%$ & $40.0 \%$ & $40.0 \%$ & $30.0 \%$ & $40.0 \%$ & $20.0 \%$ \\
\hline Total & $16.7 \%$ & $20.0 \%$ & $36.0 \%$ & $36.0 \%$ & $40.0 \%$ & $40.0 \%$ & $36.0 \%$ & $40.0 \%$ \\
\hline
\end{tabular}

n.d.: non-determinable, total: over all treatments.

meconium samples [11], which confirmed that the gastrointestinal tract of a foetus is sterile [23]. In mares, bacterial flora remained largely stable from 14 days before until 42 days after foaling, whereas the presence of bacterial species and intensity of bacterial growth changed over time in foals [2]. These results were confirmed in our study, as aerobic and anaerobic bacteria (data not shown), but also lactobacilli, enterococci and $C$. perfringens counts in the faeces of the foals increased after birth until day 3 or day 9 . Foals start to consume forages and concentrates very early in life. As a result, the intestinal microflora is adapting rapidly to improve digestion of the feed. In foals, there may be great genetic selective pressure for early colonisation of microflora to avoid acidic stomach conditions and to occupy a more distal region (post-gastric) than would be the case in calves or lambs [24]. By day 58 of a foal's life, aerobic and anaerobic bacteria, enterobacteria, lactobacilli, and enterococci had decreased to the levels in the faeces of mares (measured at the time of birth). These changes seemed to be related to the stabilisation of microflora by increasing fibre intake and digestion processes within the first 2 months of the foal's life.

Bacillus cereus var. toyoi did not have any effects on the health status of the foals. There is a great diversity of bacteriophages, bacteria, fungi, and protozoa that might have an unselective entry to the gastrointestinal tract of

\begin{tabular}{|c|c|c|c|c|c|c|c|c|}
\hline \multirow[t]{2}{*}{ Group } & \multicolumn{8}{|c|}{ Day of foal's life } \\
\hline & 1 & 3 & 9 & 16 & 23 & 30 & 44 & 58 \\
\hline Placebo & $50.0 \%$ & $100 \%$ & $42.9 \%$ & $25.0 \%$ & $12.5 \%$ & $0 \%$ & $0 \%$ & $0 \%$ \\
\hline D & $71.4 \%$ & n.d. & $71.4 \%$ & $71.4 \%$ & $28.6 \%$ & $14.3 \%$ & $14.3 \%$ & $28.6 \%$ \\
\hline HD & $60.0 \%$ & $66.7 \%$ & $90.0 \%$ & $60.0 \%$ & $10.0 \%$ & $0 \%$ & $0 \%$ & $0 \%$ \\
\hline otal & $61.1 \%$ & $80.0 \%$ & $70.8 \%$ & $52.0 \%$ & $16.0 \%$ & $4.0 \%$ & $4.0 \%$ & $8.0 \%$ \\
\hline
\end{tabular}

n.d.: non-determinable, total: over all treatments. the foals. Therefore, even if probiotic bacteria survive the acidic conditions after day 2 of life, they will experience heavy competition within the very rapidly developing intestinal microflora of foals.

Probiotic supplementation with Lactobacillus pentosus WE7 was significantly associated with development of signs of depression, anorexia, and colic in foals [12]. Also, supplementation with Lactobacillus rhamnosus and Enterococcus faecium led to increased diarrhoea in foals [11]. In contrast, we found that supplementation with $B$. cereus var. toyoi had no effect on the growth and health parameters in foals kept under high-quality standard husbandry.

\section{Conclusions}

Supplementation with $B$. cereus var. toyoi had no effect on health status or the intestinal microflora in suckling foals. Diarrhoea occurred in up to $90 \%$ of the foals for at least one 1 day between days 8 and 16 of life. Despite this, foals remained bright and alert and continued to nurse. Diarrhoea might be a part of the normal physiological development of the intestinal microflora. Competition with diverse, rapidly colonizing intestinal microflora seems to suppress B. cereus var. toyoi and its possible effects.

\section{Methods \\ Animals}

The project (V54-19c20/15-V/04) was approved by the Ethics Committee for Animal Rights Protection of the District government in Darmstadt, in accordance with German legislation for animal rights and welfare.

A total of 25 mares and their foals with one thoroughbred stud were included in the study. The mares had been stabled at least 2 months before foaling at the stud farm. Mares were kept in separate stalls with straw beddings and were turned out daily on sand paddocks for several hours every day. They were fed ad libitum haylage or hay and 2-3 $\mathrm{kg}$ of concentrates per day. Mares had free access to fresh water at all times. Foals were born between February and May 2011. Twenty-two foals first came into contact with the mares' udder within the first hour of life, and 1 foal required $90 \mathrm{~min}$. (In the other two mares, foaling was not observed.) Mares were dewormed with ivermectin immediately after foaling and 2-3 months post partum. After foaling, mares were fed ad libitum hay, 4-5 $\mathrm{kg}$ of alfalfa hay, and $2-3 \mathrm{~kg}$ of a complement feed per day (Equilac Zuchtstutenfutter Spezial Etzean; Additional file 1: Table S1). Passive transfer of antibodies was controlled with SNAP Foal IgG Test (Idexx Laboratories, Westbrook, Maine, USA). Twenty-four of the 25 foals had immunoglobulin levels of $>800 \mathrm{mg} / \mathrm{dL}$ at $12 \mathrm{~h}$ of age. 


\section{Feeding}

In the first weeks of life foals had access to the mare's feed. From day 2 of the foal's life, the mare and foal were turned out on sand paddocks twice a day for 1-2 h. From day 7 to 14, two mares and foals had access to pasture twice a day for 2 to $4 \mathrm{~h}$. At this time, no additional alfalfa hay was fed to the mares. From 4 to 8 weeks, groups of mares and foals were turned out on pasture and foals were fed complement feed for foals $(1.7-2.5 \mathrm{~kg}$ per foal; Fohlenfutter Spezial Etzean; Additional file 1: Table S1) in a separate area. Once or twice a week foals were given $50 \mathrm{~mL}$ of a mineral mixture (Meganutril junior; Additional file 1: Table $\mathrm{S} 1$ ).

\section{Deworming and treatments}

All foals received pyrantel in week 2 of life, ivermectin in week 8 , and pyrantel in month 4 . Five foals were treated for an omphalic inflammation with cefquinome or trimethoprim-sulfadimethoxine at day 2-4 or at day 24-26 of foals life, two foals were treated for congenital neuromyodysplasia with oxytetracycline at day 2-4 of foals life and three foals were treated because of highgrade diarrhoea with cefquinome or trimethoprimsulfadimethoxine at day 24-26 of foals life.

\section{Probiotic and administration protocol}

Bacillus cereus var. toyoi was provided as an odourless, white to greyish-brown dry powder supplemented with $1.0 \times 10^{10}$ viable spores of $B$. cereus var. toyoi per gram. The viability was confirmed at the beginning of the study by use of the microbiological spread plate method.

Foals were randomly allocated to three groups and received their respective placebo or supplement once a day orally for 58 days, starting on the first day of life. Eight foals were given $10 \mathrm{~mL}$ of isotonic saline solution (placebo), seven foals received $5.0 \times 10^{8} \mathrm{cfu}$ of $B$. cereus var. toyoi (low dosage, LD), and ten foals were given $2.0 \times 10^{9} \mathrm{cfu}$ of $B$. cereus var. toyoi (high dosage, HD).

\section{Examinations and faeces samples}

Behaviour, appetite, heart and respiratory rates, rectal temperature, and body weights were monitored during the treatment period (day 1 to 58 of life) and monthly from age 3 to 5 months. Blood work was done four times in month 1 and at the end of month 2 . The time schedule of the study is given in Table 6 .

Within the first day of life, on days 9, 16, 23, 30, 44, and 58, and on the first day of diarrhoea faecal samples were taken from the rectum or by the use of a collection bag. Faeces were visually classified by a faeces score (Table 7), and faeces dry matter content was determined after oven-drying $\left(103^{\circ} \mathrm{C}\right)$ to constant mass.
Table 6 Time schedule of the study

\begin{tabular}{|c|c|c|c|c|c|c|c|c|c|c|c|c|c|c|c|}
\hline \multirow[t]{2}{*}{ Measure } & \multicolumn{12}{|c|}{ Day of foal's life } & \multicolumn{3}{|c|}{$\begin{array}{l}\text { Month of } \\
\text { foal's life }\end{array}$} \\
\hline & 1 & 4 & 6 & 9* & 10 & 12 & 14 & 16 & 23 & 30 & 44 & 58 & 3 & 4 & 5 \\
\hline $\begin{array}{l}\text { Health } \\
\text { status }\end{array}$ & $x$ & $X$ & $X$ & $x$ & $x$ & $x$ & $x$ & $x$ & $x$ & $x$ & $X$ & $X$ & $x$ & $x$ & $x$ \\
\hline $\begin{array}{l}\text { Body } \\
\text { weight }\end{array}$ & $x$ & & & $x$ & & & & $x$ & $x$ & $x$ & $x$ & $x$ & $x$ & $x$ & $x$ \\
\hline Faeces & $x$ & & & $x$ & & & & $x$ & $x$ & $x$ & $x$ & $x$ & & & \\
\hline Blood & $x$ & & & $x$ & & & & $x$ & & $x$ & & $x$ & & & \\
\hline
\end{tabular}

*Additional measurements and sampling were done on the first day of diarrhoea.

Mares' faeces were taken from the rectum immediately after foaling. Faeces samples were frozen at $-18^{\circ} \mathrm{C}$ until analysis.

\section{Haematology and serum chemistry analysis}

Serum and EDTA blood was subjected to haematology and serum chemistry determination. The parameters of red blood count and differential leukocyte count were determined photometric, optical or calculated using an ADVIA $^{\circledR} 120$ haematology system (Fa. Bayer Vital GmbH, Fernwald, Germany).

Serum-IgG was determined quantitatively with a competitive ELISA as previously described by Schroedl et al. [25]. Thereby serum-IgG in the samples and equine IgG conjugated to peroxidase (purity according to SDSPAGE $>90 \%$ ) competed for antibodies against equine IgG. After washing and the addition of a chromogenic substrate quantity of peroxidase was optically measurable at $405 \mathrm{~nm}$ (reference wavelength $492 \mathrm{~nm}$ ). Equine reference serum was used as standard. Out of the measuring data IgG concentration was calculated with Table Curve 2D v4 (Systat Software Inc, Chicago, USA). Limit of detection with a serum dilution factor of 4000 was $0.15 \mathrm{~g} / \mathrm{l}$. The level of specificity was at $100 \%$.

Table 7 Faeces score

\begin{tabular}{ll}
\hline Score & Faeces quality \\
\hline 0 & Orange-brownish first faeces after meconium \\
1 & Dry balled \\
2 & Soft balled, formed \\
3 & Not formed, soft \\
4 & Pasty \\
5 & Mushy \\
6 & Inhomogeneous: structured and watery part \\
7 & Mucous like \\
8 & Green diarrhoea \\
9 & Yellow diarrhoea \\
\hline
\end{tabular}




\section{Bacterial analysis}

Faecal specimens $(0.5 \mathrm{~g}$ in $4.5 \mathrm{~mL}$ phosphate buffered saline) were serially diluted in phosphate buffered saline for quantitative bacterial investigations. Dilutions were tested for total aerobic cell numbers developing on sheep blood agar (Oxoid, Germany), gram negative cell numbers on Gassner agar (SIFIN, Berlin), Enterococci on Citrate azide tween carbonate agar (CATC agar, SIFIN, Berlin), total anaerobe cell numbers on sheep blood agar (OXOID, Germany), Lactobacilli on deMan, Rogosa and Sharpe Lactobacillus agar (MRSA agar, SIFIN, Berlin), Bacteroides spp. on sheep blood agar supplemented with vitamin $\mathrm{K}$, Clostridium perfringens on sheep blood agar containing polymyxin $\mathrm{B}$ and neomycin, and yeasts and fungi on Sabouraud agar (SIFIN, Berlin). The total aerobic cell numbers, gram negative cell numbers and enterococci were cultured aerobically at 37 C for $24 \mathrm{~h}$. The anaerobic bacteria were cultured at 37 C for $48 \mathrm{~h}$ in anaerobic chamber (MACS anaerobic workstation, Don Whitley Scientific limited, England). Yeasts and fungi were cultured aerobically at 37 _C for 5 days. The different isolated strains were identified based on their characteristic colony- and micromorphology and by their biochemical characteristics according to Bisping and Amtsberg [26] and finally analyzed with the use of matrix-assisted laser desorption/ionization time of flight (MALDI-TOF) as described by Shehata et al. [27].

\section{Statistical analysis}

Data are expressed as median, 25\% quartile, and 75\% quartile. Data analysis was performed by the Statistica software program (StatSoft, Hamburg, Germany). The Shapiro-Wilk test was used to assess data for normality. Data were not normally distributed. Non-parametric tests (Kruskal-Wallis ANOVA) were used to compare the effects of time and diet. Pearson's chi-squared test was used to compare the frequency of foals with diarrhoea between treatments.

Statistical significance was accepted at $P<0.05$.

\section{Additional file}

Additional file 1: Table S1. Nutrient composition of the feedstuffs provided to the foals and mares during experimental period (expressed in \%).

\section{Abbreviations \\ B. cereus var. toyoi: Bacillus cereus var. toyoi; C. perfringens: Clostridium perfringens; HD: High dosage $\left(5.0 \times 10^{8} \mathrm{cfu}\right.$ of $B$. cereus var. toyoi); LD: Low dosage $\left(2.0 \times 10^{9}\right.$ cfu of $B$. cereus var. toyoi).}

\section{Competing interests}

Rubinum Animal Health supplied Bacillus cereus var. toyoi, the probiotic used in this study. Rubinum Animal Health played no role in the study design or in the collection, analysis, and interpretation of data, nor in the decision to submit the manuscript for publication. None of the authors has any financial or personal relationships that could inappropriately influence or bias the content of the paper.

\section{Authors' contributions}

JJ has made substantial contributions to acquisition, analysis and interpretation of data, helped to perform the statistical analysis and drafted the manuscript. KR has made contributions to conception of the study and helped to acquire data. WS has revised the manuscript critically for important intellectual content and has given final approval of the version to be published. NA carried out the bacterial analysis. IV conceived the study, and participated in its design and coordination, performed the statistical analysis and helped to draft the manuscript. All authors read and approved the final manuscript.

\section{Acknowledgements}

The authors are grateful to the team at Etzean Stud. We wish to thank Jana Tietke for her technical assistance. We acknowledge support from the German Research

Foundation (DFG) and the Leipzig University within the programme of Open Access Publishing.

\section{Author details}

Institute of Animal Nutrition, Nutrition Diseases and Dietetics, Faculty of Veterinary Medicine, University of Leipzig, Leipzig, Germany. ${ }^{2}$ Pferdeklinik Großostheim, Großostheim, Germany. ${ }^{3}$ Institute of Bacteriology and Mycology, Faculty of Veterinary Medicine, University of Leipzig, Leipzig, Germany. ${ }^{4}$ Present address: Tierklinik Teisendorf, Teisendorf, Germany.

Received: 24 July 2014 Accepted: 6 February 2015

Published online: 14 February 2015

\section{References}

1. Masri MD, Merritt AM, Gronwall R, Burrows CF. Faecal composition in foal heat diarrhoea. Equine Vet J. 1986:18:301-6.

2. Kuhl J, Winterhoff N, Wulf M, Schweigert FJ, Schwendenwein I, Bruckmaier RM, et al. Changes in faecal bacteria and metabolic parameters in foals during the first six weeks of life. Vet Microbiol. 2011;151:321-8.

3. Magdesian KG. Neonatal foal diarrhea. Vet Clin North Am Equine Pract. 2005;21:295-312

4. Knottenbelt DC, Holdstock N, Madigan JE. Diarrhö. In: Knottenbelt DC, editor. Neonatologie der Pferde. 1st ed. München: Elsevier, Urban \& Fischer, München; 2007. p. 265-88.

5. Dunkel B. Infectious foal diarrhoea: pathophysiology, prevalence and diagnosis. Equine Vet Educ. 2004;16(2):94-101.

6. Velde K, Kolm G. Entzündlich und funktionell bedingte Störungen des Darms. In: Fey K, Kolm G, editors. Fohlenmedizin. 1st ed. Stuttgart: Enke; 2011. p. 327-37.

7. Julliand V, De Vaux A, Villard L, Richard Y. Preliminary studies on the bacterial flora of faeces taken from foals, from birth to twelve weeks: effects of the oral administration of a commercial colostrum replacer. Pferdeheilkunde. 1996;12:209-12.

8. Sadet-Bourgeteau S, Julliand V. Equine microbial gastro-intestinal health. In: Ellis AD, Longland AC, Coenen M, Miraglia N, editors. The Impact of Nutrition on the Health and Welfare of Horses, EAAP Publications, vol. 128. Cirencester: Wageningen Academic Publishers; 2010. p. 161-82.

9. $\mathrm{FAO}, \mathrm{WHO}$. Report of a joint $\mathrm{FAO} / \mathrm{WHO}$ expert consultation on evaluation of health and nutritional properties of probiotics in food including powder milk with live lactic acid bacteria. In: Health and Nutritional Properties of Probiotics in Food Including Powder Milk with Live Lactic Acid Bacteria. 2001. ftp://ftp.fao.org/docrep/fao/009/a0512e/a0512e00.pdf.

10. Yuyama T, Yusa S, Takai S, Tsubaki S, Kado Y, Morotomi M. Evaluation of a host-specific Lactobacillus probiotic in neonatal foals. Int J Appl Res Vet Med. 2004;2:26-33

11. Günther E, Ströbel C, Romanowski K, Urubschurov V, Büsing K, Souffrant W, et al. Effects of probiotic strains of Enterococcus faecium and Lactobacillus rhamnosus on diarrhoea patterns and the faecal microbiome of sucking foals. In: Szymeczko R, Iben C, Burlikowska K, Sitkowska B, editors. Proceedings of the16th Congress of the European Society of Veterinary and Comparative Nutrition: 13-15 September 2012; Bydgoszcz. Multiskop Sp: Z o.0; 2012. p. 79.

12. Weese JS, Rousseau J. Evaluation of Lactobacillus pentosus WE7 for prevention of diarrhea in neonatal foals. J Am Vet Med Assoc. 2005;226:2031-4.

13. Erhard $\mathbf{M H}$, Leuzinger $K$, Stangassinger $M$. Untersuchungen zur prophylaktischen Wirkung der Verfütterung eines Probiotikums und von 
erregerspezifischen Kolostrum- und Dotterantikörpern bei neugeborenen Kälbern. J Anim Physiol Anim Nutr. 2000;84:85-94.

14. Jadamus A, Vahjen W, Simon O. Growth behavior of a spore forming probiotic strain in the gastrointestinal tract of broiler chicken and piglets. Arch Anim Nutr. 2001;54:1-17.

15. Vilà B, Fontgibell A, Badiola I, Esteve-Garcia E, Jiménez G, Castillo M, et al. Reduction of Salmonella enterica var. enteritidis colonization and invasion by Bacillus cereus var. toyoi inclusion in poultry feeds. Poult Sci. 2009:88:975-9.

16. Matusevicius P, Bartkeviciute Z, Cernauskenie J, Kozlowski K, Jeroch H. Effect of probiotic preparation "Toyocerin" and phytogenic preparation "Cuxarom Spicemaster" in growing rabbits. Eur Poult Sci. 2011;75(1):67-71.

17. Baum B, Liebler-Tenorio EM, Enß ML, Pohlenz JF, Breves G. Saccharomyces boulardii and Bacillus cereus var. toyoi influence the morphology and the mucins of the intestine of pigs. Z Gastroenterol. 2002;40:277-84

18. Lahrssen M, Zentek J. Wirksamkeit von probiotischen Mikroorganismen als Futterzusatzstoff: Leitlinien zur Prüfung der Wirksamkeit bei den Tierkategorien Hund, Katze und Pferd. TierarztI Wochenschr. 2002;109(1):22-5.

19. Jeroch H, Strobel E, Zachmann R. Untersuchungen zur Wirksamkeit des Probiotikums Bacillus cereus toyoi in der Putenmast. Vetarinarija Ir Zootechnika. 2004;28(50):57-60.

20. Jadamus A, Vahjen W, Schäfer K, Simon O. Influence of the probiotic strain Bacillus cereus var. toyoi on the development of enterobacterial growth and on selected parameters of bacterial metabolism in digesta samples of piglets. J Anim Physiol Nutr. 2002;86:42-54.

21. Julliand V, Goachet AG. Fecal microflora as a marker of cecal or colonic microflora in horses. In: Proceedings of the19th Equine Science Symposium: 31 May- 3 June. Tucson; 2005. p. 140-1.

22. Sakaitani Y, Yuki N, Nakajima F, Nakanishi S, Tanaka H, Tanaka R, et al. Colonization of intestinal microflora in newborn foals. J Intestinal Microbiol. 1999:13:9-14.

23. Mackie Rl, Sghir A, Gaskins HR. Developmental microbial ecology of the neonatal gastrointestinal tract. Am J Clin Nutr. 1999;69:1035S-45.

24. Egan CE, Snelling TJ, Mc-Ewan NR. The onset of ciliate populations in newborn foals. Acta Protozool. 2010;49:145-7.

25. Schroedl W, Jaekel L, Krueger M. C-reactive protein and antibacterial activity in blood plasma of colostrum-fed calves and the effect of lactulose. J Dairy Sci. 2003;8:3313-20.

26. Bisping W, Amtsberg G. Colour Atlas for the Diagnosis of Bacterial Pathogens in Animals. Verlag Berlin: Paul Parey; 1988.

27. Shehata A, Schrödl W, Neuhaus J, Krüger M. Antagonistic effect of different bacteria on Clostridium botulinum types $A, B, D$ and $E$ in vitro. Vet Rec. 2013;172:47

\section{Submit your next manuscript to BioMed Central and take full advantage of:}

- Convenient online submission

- Thorough peer review

- No space constraints or color figure charges

- Immediate publication on acceptance

- Inclusion in PubMed, CAS, Scopus and Google Scholar

- Research which is freely available for redistribution 